\title{
Impact of GDP and FII on Stock Market: A Study in BSE and NSE in India
}

\author{
Aditya Prasad Sahoo \\ Research Scholar, KIIT University, Bhubaneswar, Odisha, India \\ https://orcid.org/0000-0003-4399-2604
}

\section{OPEN ACCESS}

Manuscript ID:

COM-2021-09013529

Volume: 9

Issue: 1

Month: January

Year: 2021

E-ISSN: 2582-6190

Received: 15.09.2020

Accepted: 01.11.2020

Published: 01.01.2021

Citation:

Sahoo, Aditya Prasad.

"Impact of GDP and FII on Stock Market: A Study in BSE and NSE in India." ComFin Research, vol. 9, no. 1, 2021, pp. 47-51.

DOI:

https://doi.org/10.34293/

commerce.v9i1.3529

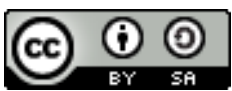

This work is licensed under a Creative Commons Attribution-ShareAlike 4.0 International License

\begin{abstract}
The researchers studied the effect of GDP and FII on the working of the Indian Stock Market. The monthly details of GDP, FII, BSE and NSE are used to accomplish the study's aims. To find out the findings, the Augmented Dickey Fuller (ADF) Test, Multiple Regression and Granger Causality Experiments have been used. Foreign portfolio investors were stationary at the level of GDP and $G D P$ at the first gap. From the study, it is found that both the independent variables were significant on the dependent variable NSE and BSE. To check the causality relationship between GDP, FII and NSE, the BSE Granger causality model has been used. To find out the results, average closing prices of BSE and NSE for 15 years, i.e. from 2000-2015, have been collected. It has been observed that both GDP and FII possess a significant impact on the indices of BSE NSE. As per the findings, the Stock Market in India was efficient, considering these two variables and found a significant relationship during the study period.
\end{abstract}

Keywords: GDP, FII, NSE, BSE, ADF test, Garner causality, Regression

\section{Introduction}

A generic term relates to a regulated exchange where equity shares are exchanged indeed the stock market. Stock market activity relies mostly on investor's logical as well as aberrant behavior. Macro-economic factors like GDP and FIIs would also affect the overall returns in the stock market. Development is evaluated in terms of a rise in the size of the economy of a country. A large measurement of the production of an economy. Gross Domestic Product is the most commonly used indicator of economic production. Gross Domestic Product (GDP), a measure of measurement in national accounting, is defined as the total value, irrespective of ownership, of the final products and services generated within the boundaries of a country in one year. In September 1992, Foreign Institutional Investors (FIIs) were authorized to invest in all of the listed shares traded on the Indian stock market for the first time. According to the RBI Currency \& Finance Report (2003-04), there has been a persistent movement toward integrating the Indian economy with the global system since 1991. Ever since, the laws surrounding investment in FIIs were much more flexible. India got enormous amounts of foreign capital, especially from developed countries, due to the abolition of obstacles to capital inflows in the form of FII investment. At the end of March 2007, the total net investment of FIIs in the Indian stock market since 1993 had exceeded US\$ 50 billion (SEBI, Annual Report, 200607). All foreign remittances of capital have a significant impact on the health of the recipient country. On a brighter note, by rising consumption expenditure and extending liquidity management, these capital inflows increase economic growth. The research will therefore be performed to know the effect on stock market returns of GDP and FII and to discover the essence and strength of the association between the vector under analysis. 


\section{Review of Literature}

The causal relation between stock returns and macroeconomic variables in Norway was investigated by Gjrde and Saettem (1999). The analysis indicates a positive association between the cost of crude, output growth and returns on stocks. Flannery and Protopapadakis (2002) noted that different common indicators (real GDP growth rate and industrial output) of economic growth had not been connected to share prices. Mokerjee and Qiao (1997) studied the co-integration of stock values both with money supply measurements (M1 and M2) and net foreign currency reserves. The association among the stock market and IPI, money supply, CPI and the exchange rate in Malaysia was analyzed by Ibrahim and Aziz (2003). It was found that stock prices have a favorable deep connection with IPI and CPI. The deep connection seen between the underlying stock market and macroeconomic variables was studied by Cheng and $\mathrm{Ng}$ (1998) and Sharma (2002). The findings indicate that share prices would be strongly associated with growth and production in the long term. Ben et al. (2007) and Charles (2008) find that the key factors of stock market growth are saving rate, growth of the banking sector, intermediaries of finance, liquidity of the stock market and the stabilization component. Uddin and Alam $(2007,2009)$ find a serious adverse association between the rate of interest and the stock value. The effect of macroeconomic indexes on the Ghana Stock Exchange (GSE) was investigated by Coleman and Tettey (2008) and inferred that loan rates from deposit money banks and inflation bear a negative effect on share index performance, contrary to the conclusions of Adam and Tweneboah (2008). Rahman et al. (2009) revealed a significant long-term impact of liquidity measures on the Malaysian stock exchange. Pal and Mittal (2011) find that the shift in a few chosen macroeconomic factors influences shifts in Indian financial markets. Ray (2012) points out that between share price and inflation, FDI, GDP, and exchange rate, a unidirectional causal relationship occurs.

\section{Objectives of the Study}

1. To study the relationship between stock market returns concerning GDP and FIIs.
2. To find the between stock market returns concerning GDP and FIIs.

3. To check the efficiency of the Indian Stock Market concerning GDP and FIIs.

\section{Methodology}

The relevance of this thesis derives from the critical role that the Stock market has performed in improving the economy of India. The biggest goal achieved by this is to raise capital from customers and inspire them to participate. This study was therefore carried out to verify the impact of Gross domestic product and Institutional investors on Indian stock market results, as both parameters contribute significantly to economic growth and expansion. To verify the stationarity of results, the ADF Test was used. And Multiple Regression was introduced to figure out the significant variables when the data were static. After several regressions, the Granger causality test was used to examine the casual association between the dependent and independent variables. For those who find it important after multiple linear regression outcomes, the causal association was verified. This study is based on secondary resources collected from journals, NSE and BSE websites, money control, capital line IQ, and other reliable sources from RBI and the Handbook of statistics.

\section{Hypothesis}

H1: All the variables in the study are nonstationery.

$\mathrm{H} 2$ : There is a significant relationship exist between GDP and FII with Indian stock market performance indicators NSE and BSE.

H3: GDP and FII Granger Cause NSE and BSE during the study period.

H4: NSE and BSE Granger Cause GDP and FII during the study period.

\section{Data Analysis and Interpretation \\ Stationarity Test of all the variables}

It is generally found that unit root exists in financial series of data. The order of the data, either non-stationary or random. A unit root test in this study is necessary to check the stationarity of all the variables in the study. As the unit root data will give 
misleading results, making all the data stationary, of all the variables in this study ADF test has been implemented, which is the most popular statistical tool for measurement of stationarity in a data set.

Table 1: Stationarity Test of Data

\begin{tabular}{|c|c|c|c|c|c|}
\hline \multicolumn{7}{|c|}{ ADF Test for stationarity of relevant data } \\
\hline Factors & Level & First level & 2nd level & H1 & Findings \\
\hline BSE & $3.394868(1.0000)$ & $-4.572732(0.0000)$ & - & 1st level (Rejected) & Stationary (1st level) \\
\hline NSE & $2.345269(0.1601)$ & $-5.288582(0.0000)$ & - & 1st level (Rejected) & Stationary (1st level) \\
\hline GDP & $1.544632(0.5069)$ & $-7.489183(0.0000)$ & - & 1st level (Rejected) & Stationary (1st level) \\
\hline FIIs & $-6.19638(0.0000)$ & - & - & At level (Not accepted) & Stationary (At level) \\
\hline
\end{tabular}

Source: Author's calculation and E-VIEW

From the analysis of Table 1, it is found that FII is stationary at the level and other variables such as GDP, BSE, NSE are stationary at 1st difference at significance level 0.05 percent.

\section{Significant Relationship by using Regression}

Regression analysis presents a method that can concurrently combine the relationship of motives with more than two variables. This methodology has been used to test the effects of GDP and FIIs on the Indian stock market. The results are summarized in Table 2, which demonstrates the relationship between GDP and FII with the performance of the stock market in India.

Table 2: Regression statistics of GDP and FIIs with NSE and BSE

\begin{tabular}{|c|c|c|c|c|c|}
\hline \multicolumn{7}{|c|}{ Regression Analysis } \\
\hline Regression with NSE \\
\hline Variable & Coefficient & Std. Error & t-Statistic & Prob. & Results \\
\hline GDP & 0.00052 & $4.23 E-08$ & 5.5379 & 0.1104 & H2 Accepted \\
\hline FIIs & -0.0015 & 0.00332 & -0.96542 & 0.0701 & H2 Accepted \\
\hline \multicolumn{7}{|c|}{ Regression with BSE } \\
\hline Variable & Coefficient & Std. Error & t-Statistic & Prob. & Results \\
\hline GDP & -0.84521 & 0.373546 & -2.26266 & 0.0759 & H2 Accepted \\
\hline FIIs & 0.015208 & 0.022573 & 0.673717 & 0.0621 & H2 Accepted \\
\hline
\end{tabular}

Source: Author's calculation and SPSS

From Table 2, it can be concluded that both the macroeconomic variables have a significant relationship with BSE and NSE during the period of study at a 5\% significance level. Both the GDP and FII found significant in building a relationship with its dependent variable. The $p$-value of GDP is 0.0759 and the P-Value of FII is 0.0621 . Similarly, a p-value of GDP is 0.1104 and the P-Value of FII is 0.070 in the case of regression analysis with the BSE. Both the independent variables' P-value is higher than the significant level of 0.05 with two different dependent variables. This leads to acceptance of hypothesis $\mathrm{H} 2$ that there is a significant relationship exists between NSE, BSE and Macroeconomic variables like GDP and FII.

\section{Test Results in Causal Relationship}

Granger Causality is a mathematical method suggested by Clive W Granger to conclude causality interactions among two different time series. Granger Causality is based on a fundamental rationale that no cause can be preceded by the effect. It is worth noting that the "x Granger causes y" statement does not signify that $y$ is the effect or outcome of $x$. Granger Causality, in other terms, is a tool for evaluating how one data series is beneficial in predicting another. During the research period from 2004 to 2018, this segment examined the causal correlation between the share market indices NSE, BSE and two independent variables, GDP and FIIs. 
Table 3: Granger Causality Test

\begin{tabular}{|c|c|c|c|c|c|}
\hline \multicolumn{6}{|c|}{ BSE } \\
\hline Null Hypothesis: & Observation & F-Statistic & Prob. (p Value) & Result & Relationship \\
\hline GDP Granger Cause BSE & 105 & 0.51625 & 0.6626 & H3 accepted & Relation \\
\hline BSEGranger Cause GDP & & 0.02187 & 0.0453 & H3 rejected & No relation \\
\hline FII Granger Cause BSE & 105 & 1.26551 & 0.1101 & H3 accepted & Relation \\
\hline BSEGranger Cause FII & & 1.16861 & 0.0273 & $\mathrm{H} 3$ rejected & No relation \\
\hline BSE Granger Cause GDP and FII & 105 & 0.41025 & 0.0492 & H3 rejected & No Relation \\
\hline GDP and FII Granger Cause BSE & & 1.98586 & 0.0371 & H3 accepted & No relation \\
\hline \multicolumn{6}{|c|}{ NSE } \\
\hline Null Hypothesis: & Observation & F-Statistic & Prob. (p Value) & Result & Relationship \\
\hline GDP Granger Cause NSE & 105 & 0.25523 & 0.6626 & H3 accepted & Relation \\
\hline NSE Granger Cause GDP & & 0.09134 & 0.0125 & H4 rejected & No relation \\
\hline FII Granger Cause GDP and FII & 105 & 0.31272 & 0.1101 & H3 accepted & Relation \\
\hline NSE Granger Cause FII & & 1.16861 & 0.0315 & H4 rejected & No relation \\
\hline NSE Granger Cause GDP and FII & 105 & 1.62354 & 0.03749 & H3 rejected & No Relation \\
\hline GDP and FII Granger Cause NSE & & 1.98586 & 0.1426 & H4 accepted & Relation \\
\hline
\end{tabular}

Source: Author's calculation and E-VIEWS

Table 3 presents the results of Granger causality test between GDP, FII and Stock market indices in India BSE and NSE. Both the independent variable GDP and FII in the above analysis were found significant. But in the case of NSE and BSE, both were found insignificant. As per the study, Both the variables GDP and FII granger cause both NSE and $\mathrm{BSE}$ as P-value is higher than 0.05 level, accepting the hypothesis H4 that GDP and FII Granger Cause both NSE and BSE. Whereas in the case of analysis of Causal relationship between NSE and BSE, it is found that P-value in both the analysis is lower than the significant level 0.05 , rejecting the Hypothesis $\mathrm{H} 4$ that NSE and BSE granger cause GDP and FII. It is clear from the analysis that unidirectional relationship exists between GDP and FII with Indian stock market performance during the study period.

\section{Conclusion}

The goal of this research was to figure out if, during the study times, the Indian Stock Market is influenced by GDP and FII. ADF test, together with multiple regression and granger causality, were used to verify this impact. The stationary data has been used through regression analysis approaches to discover the important influence of GDP and FII. It was observed that both the exogenous variables GDP and FII were important. With the Granger Causality methodology, the causality relation between two independent parameters and monthly index data of both the NSE and BSE was checked. The unidirectional correlation between GDP and FII with the success of the share market has been created. It is concluded that India's stock market was productive and affected by GDP and FII during the study. In the market, it is clear that all stock market information is available to all. It is clinched that a good investment decision can be formulated by properly analyzing the macro factors' impact to maximize the desired return from the investment.

\section{References}

Ahmed, Shahid. "Aggregate Economic Variables and Stock Market in India." International Research Journal of Finance and Economics, 2008, pp. 141-164.

Bhunia, Amalendu. "The Shock of the Shock of Crude Price, Stock Price and Selected Macroeconomic Variables on the Growth of Indian Economy." Sumedha Journal of Management, vol. 1, no. 2, 2012, pp. 82-89.

Goudarzi, Hojatallah, and C.S. Ramanarayanan. "Empirical Analysis of the Impact of Foreign Institutional Investment on the Indian Stock 
Market Volatility during World Financial Crisis." International Journal of Economics and Finance, vol. 3, no. 3, 2011, pp. 214-226. Hosseini, Seyed Mehdi, et al. "The Role of Macroeconomic Variables on Stock Market Index in China and India." International Journal of Economics and Finance, vol. 3, no. 6, 2011, pp. 233-243.

Jha, Amit Kumar, and Nitesh Kumar Singh. "Predicting the Volatility of Stock Markets and Measuring its Interaction with Macroeconomic variables: Indian Evidence,Case Study of NIFTY \& SENSEX." International Journal of Sciences: Basic \& Applied Research, vol. 13, no. 1, 2014, pp. 371-393.

Kalra, Rosy. "Impact of Macroeconomic Variables on Indian Stock Market." IUP Journal of Financial Risk Management, vol. IX, no. 1, 2012, pp. 43-54.

Kumar, Ashish. "An Empirical Analysis of Causal Relationship between Stock Market and Macroeconomic Variables in India." International Journal of Computer Science and Management Studies, vol. 11, no. 1, 2011, pp. 8-14.

Kumar, Rakesh. "The Effect of Macroeconomic Factors on Indian Stock Market Performance: A Factor Analysis Approach." IOSR Journal of Economics and Finance, vol. 1, no. 3, 2013, pp. 14-21.

Mishra, Sagarika, and Harminder Singh. "Do Macroeconomic Variables explain Stock Market Returns? Evidence using a Semiparametric Approach." Journal of Asset
Management, vol. 13, no. 2, 2012, pp. 115-127.

Mohanamani, P., and T. Sivagnanasithi. "Indian Stock Market and Aggregates Macroeconomic Variables: Time Series Analysis." IOSR Journal of Economics and Finance, vol. 3, no. 6, 2014, pp. 68-74.

Naik, Pramod Kumar, and Puja Padhi. "The Impact of Macroeconomic Fundamentals on Stock Price Revisited: Evidence from Indian Data." Eurasian Journal of Business and Economics, vol. 5, no. 10, 2012, pp. 25-44.

Naka, Atsuyuki, et al. Macroeconomic Variables and the Performance of the Indian Stock Market.

Parmar, Chetna. "Empirical Relationship among Various Macroeconomic Variables and Indian Stock Market.” International Journal of Advance Research in Computer Science and Management Studies, vol. 1, no. 6, 2013, pp. 190-197.

Patel, Samveg. "The Effect of Macroeconomic Determinants on the Performance of the Indian Stock Market." NMIMS Management Review, vol. 22, 2012, pp. 117-127.

Ray, Sarbapriya. "Foreign Exchange Reserve and its Impact on Stock Market Capitalization: Evidence from India." Research on Humanities and Social Sciences, vol. 2, no. 2, 2012, pp. 46-60.

Sahoo, Aditya Prasad, and Yajnya dutta Nayak. "A Review of Derivatives Market in India in Digital Era." Research Directions, vol. 7, no. 1, 2019, pp. 350-355.

\section{Author Details}

Aditya Prasad Sahoo, Ph. D. Research Scholar, KIIT University, Bhubaneswar, Odisha, India

Email ID: adityasahoo007@gmail.com 